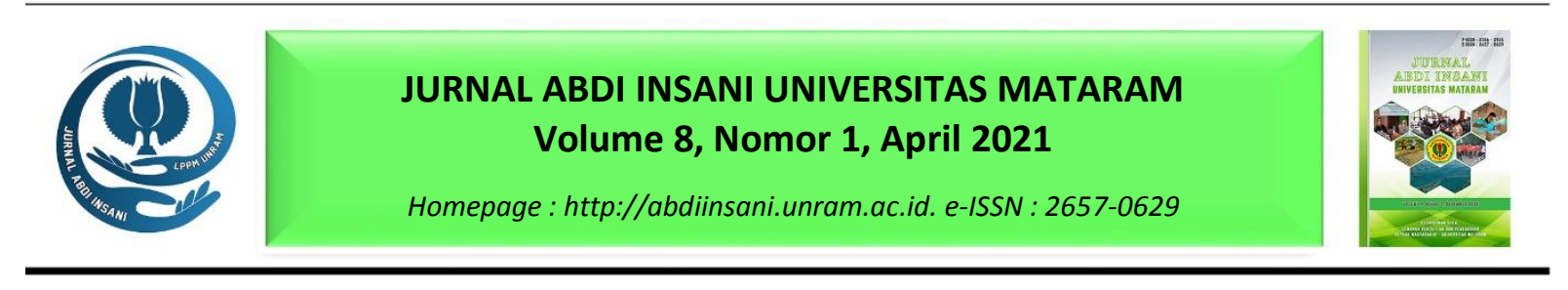

\title{
PENDAMPINGAN MASYARAKAT DESA SERUNI MUMBUL UNTUK MENJAGA DAN MENINGKATKAN KESEHATAN TUBUH PADA MASA PANDEMI COVID-19
}

\section{Seruni Mumbul Village Community Assistance To Maintain And Improve Body Health In The Covid-19 Pandemic Period}

\author{
Sudirman ${ }^{1 *}$, Dina Asnawati ${ }^{1}$, Made Ganesh Dharmayanti ${ }^{1}$, Nurul Ismillayli ${ }^{1}$, Farid Wajdi ${ }^{1}$ \\ ${ }^{1}$ Program Studi Kimia Universitas Mataram \\ Jl. Majapahit No.62 Mataram NTB
}

*Alamat korespondensi : sudirman28@unram.ac.id

(Tanggal Submission: 25 Maret 2021, Tanggal Accepted : 9 April 2021)

Keyword :
pandemi
covid-19,
pembuatan
handsatyzer,
pendampingan
masyarakat

\begin{abstract}
:
Pandemi COVID-19 memberikan dampak yang sangat besar tidak hanya secara global, namun juga hingga ke pelosok desa. Contohnya saja pada kegiatan ini yang dilakukan di Desa Seruni Mumbul Kecematam Pringgabaya Kabupaten Lombok Timur. Desa ini terletak sebelah timur pulau lombok dengan beragam etnis dan budaya. Selama masa pandemik COVID-19, masyarakat setempat juga terpantau terkena dampak baik secara ekonomi, mental dan kesehatan fisik. Hal ini dikarenakan kurangnya wawasan dalam literasi informasi, dimana perolehan informasi didominasi dari media sosial. Perangkat kesehatan yang menjadi pendukuang selama masa pendemi, juga masih bergantung dari luar. Adapun tujuan kegiatan pengabdian yang dilakukan yaitu memberikan wawasan kepada masyarakat terkait fakta-fakta ilmiah mengenai virus COVID-19 serta memberikan keterampilan dalam mejaga kesehatan khususnya dalam pembuatan handsanitizer. Hasil kegiatan yang telah dilakukan terpantau dimana masyarakat seruni mumbul yang aktif dalam mencari informasi terkait COVID-19 didominasi oleh masyarakat dengan umur 30 tahun ke bawah dimana sebagian besar dengan tingkat pendidikan SMA kebawah memperoleh informasi sebagian besar dari media sosial dengan tingkat kepercayaan yang rendah. Dengan mmebrikan pelatihan pembuatan Handsanitizer, masyarakat dapat memproduksi Handsanitizer secara mandiri. Meski demikian, pola pikir masyarakt dalam menyikapi pandemi COVID-19 masih cendrung cuek namun mulai dengan keyakinan yang optimis.
\end{abstract}

Panduan sitasi / Citation guidance (APPA $7^{\text {th }}$ edition) :

Sudirman, Asnawati, D., Dharmayanti, M. G., Ismilayli, N., \& Wajdi, F. (2021). Pendampingan Masyarakat Desa Seruni Mumbul Untuk Menjaga Dan Meningkatkan Kesehatan Tubuh Pada Masa Pandemi Covid-19. Jurnal Abdi Insani Universitas Mataram, 8 (1), 80-87. http://doi.org/10.29303/abdiinsani.v8i1.377. 


\section{PENDAHULUAN}

Pandemic yang disebabkan oleh virus COVID-19 menyebabkan kerugian dalam berbagai bidang dan sektor perekonomian pada berbagai lapisan masyarakat. Di Indonesia menebus angka 50.178 orang positif terinfeksi virus COVID-19 dan 2.620 orang meninggal akibat virus ini pertanggal 25 Juni 2020( (Naional, Gugus Tugas Percepatan Penangan Covid-19, 2020). Sementara untuk wilayah Nusa Tenggara Barat menembus angka 1.119 orang terkonfirmasi positif terinfeksi COVID-19 dengan korban meninggal sebanyak 49 orang pertanggal 24 Juni 2020 (COVID-19 NTB, 2020). Angka-angka ini masih terus terpantau dan memberikan kurva yang belum melandai. Bahkan salah satu media di Australia menyebut bahwa Indonesia akan menjadi Hotspot COVID-19 dunia (CNN Indonesia, 2020).

Tidak dapat dipungkiri, pemerintah Indonesia juga mengalami dilematika antara keberkanjutan perekonomian negara dengan kesehatan rakyat Indonesia. Wakil Ketua Umum Kamar Dagang dan Industri Indonesia (Kadin) bidang UMKM, Suryani Motik Kasus PKH (pemutusan hubungan kerja) akibat corona melonjak tanjam menembus angka 15 juta sejak pandemic ini melanda (CNN Indonesia, 2020). Hal ini menyebabkan angka penganguran juga meningkat tanjam. Tidak hanya itu, bahkan dibeberapa daerah, angka ini juga diikuti dengan peningkatan angka kriminalitas.

Oleh karena itu, Untuk menindaklanjuti amanat konstitusi tersebut, maka Gugus Tugas mempertimbangkan beberapa hal, antara lain dampak kesehatan, sosial ekonomi, dan tenaga kerja, sebagaimana arahan dari Presiden Joko Widodo untuk menentukan tahapan pembukaan sektor ekonomi. Selanjutnya Gugus Tugas juga melakukan diskusi dengan Pimpinan Kementerian/Lembaga terkait, pakar epidemiologi, kesehatan masyarakat, ekonomi kerakyatan, sosial-budaya dan keamanan. Adapun dalam pembukaan sektor ekonomi, Gugus Tugas telah mempertimbangkan risiko penularan yang menggunakan indikator kesehatan masyarakat berbasis data yakni epidemiologi, surveilans kesehatan masyarakat, dan pelayanan kesehatan. Selain itu, penilaian dampak ekonomi dilaksanakan dengan menggunakan indikator indeks dampak ekonomi dari 3 aspek yaitu aspek ketenagakerjaan, proporsi Produk Domestik Regional Bruto sektoral, dan indeks keterkaitan sektor. Adapun sembilan sektor yang ditetapkan untuk dibuka kembali meliputi; pertambangan, perminyakan, industri, konstruksi, perkebunan, pertanian dan peternakan, perikanan, logistik dan transportasi barang (Saputra, 2020).

Desa Seruni Mumbul Kecamatan Pringgabaya Kabupaten Lombok Timur adalah salah satu desa yang berbatasan langsung dengan pelabuhan kayangan dan TPI kayangan (tempat pelelangan ikan). Sehingga aktivitas kontak antar masyrakat sangat sulit untuk dihindarkan. Sebagian besar masyarakat di Desa ini banyak terlibat di sector perikanan dan perkapalan atau transportasi laut lainya antar pulau. Selain itu, Desa ini juga memiliki beberapa obyek wisata andalan yang siap dibuka kembali pada era New Normal ini. Sesuai dengan instruksi WHO dan Gugus Tugas Penangan COVID, semua sektir yang dibuka kembali harus mematuhi protocol kesehatan yang telah ditetapkan. Salah satu yang cukuo vital adalah pengadaan Handsanitizer.

Oleh karena itu, dalam kegiatan ini bertujuan memberikan pendampingan selama masa pandemi COVID-19 kepada masyarakat Desa Seruni Mumbul. Adapun kegiatan yang dilakukan selama pendampingan yaitu melakukan sosisialisasi terkait fakta-fakta ilmiah COVID-19. Selain itu, masyarakat juga diberikan keterampilan dalam membuat handsanitizer secara mandiri. Sasaran dalam kegiatan ini yaitu tim satgas COVID-19 tingkat desa yang telah dibentuk, sehingga kegiatan tetap bisa dilakukan dengan memperhatikan protokol kesehatan secara ketat. Kagitan ini diharapakan dapat mengurangi atau menangkal informasi yang kurang tepat yang seringkali membuat masyarakat resah. 
Selain itu, dengan keterampilan membuat handsanitizer secara mandiri, akan membuat masyarakat tidak perlu resah ditengah kelangkaan produk handsanitizer dipasaran.

\section{METODE KEGIATAN}

Sesuai dengan instruksi WHO dan Gugus Tugas Penangan COVID, semua sektir yang dibuka kembali harus mematuhi protocol kesehatan yang telah ditetapkan. Salah satu yang cukup vital adalah pengadaan Handsanitizer. Handsanitizer merupakan antiseptic yang secara instan dapat dipakai untuk mensterilkan tangan setelah kontak dengan orang lain untuk meminimalisir kemungkinan terjadinya infeksi. Namun dikalangan masyakarat masih belum cukup pemahaman tetang penggunaan bahan ini. Meskipun WHO telah mempublikasikan standar Handsatizer yang dianjurkan, namun masih banyak masyarakat yang menggunakan bahan-bahan strerilisasi dengan benar. Hal ini justru dapat berdampak buruk bagi kesehatan masyarakat.

Melalui kegiatan ini, akan dilakukan pelatihan kepada apparat desa dan tim satgas penanganan COVID-19 yang telah dibentuk oleh desa untuk membuat Handsanitizer sesuai dengan standar yang telah ditetapkan oleh WHO. Selain itu, pada kegiatan ini akan dilakukan pendampingan dalam memproduksi Handsanitizer oleh pihak desa. WHO mensyaratkan komposisi Handsanitizer untuk mencegas infeksi COVID-19 yaitu minimal mengandung 75\% alcohol (ethanol atau isoproil alcohol) sebagai agent antiseptic yang umum digunakan, oksidator lemah berupa hydrogen peroksida $\left(\mathrm{H}_{2} \mathrm{O}_{2}\right)$ dengan kadar maksimal $1 \%$ yang berberapan untuk membunuh bakteri atau virus yang tidak mempan terhadap alcohol. Selain itu, untuk mencegah iritasi untuk penggunaan jangka Panjang, disarankan menggunakan pelembab berupa gliserol atau lainya seperti ektrak aloe vera. Bahan tambahan bisa menggunakan beberapa tetes esensial oil untuk memberikan aroma yang lebih baik.

Kegiatan ini ditargetkan untuk membangun kemandirian Desa dalam mentaati protocol kesehatan selama melalui era new normal. Sehingga diharapkan, perekonomian dapat berjalan dengan tetap memperhatkan kesehatan masyarakat.

Kegiatan Pembinaan dan pendampingan terhadap perangkat Desa Seruni Mumbul dilaksanakan dalam beberapa tahapan kegiatan yang meliputi (i) Pra-Kegiatan, (ii) Kegiatan inti dan (iii) Evaluasi. Pra-kegiatan merupakan serangkaian kegiatan dalam mengumpulkan informasi terkait kondisi masyarakat, lingkungan dan langkah-langkah pemerintah desa dalam mengatasi permasalahan yang ada selama masa pandemi. Pengumpulan informasi dilakukan baik secara langsung dan tidak langsung. Pengumpulan informasi secara langsung diakukan dengan melakukan wawancara dengan perangkat desa, tokoh masyarakat dan beberapa warga setempat dengan tetap mematuhi protokol kesehatan COVID-19. Sedangkan untuk kegiatan pengumpulan informasi tidak secara tidak langsung, dilakukan dengan membuat quisioner online yang disebarkan oleh perangkat desa dan para pemuda karang taruna desa setempat.

Setelah mendapatkan gambaran situasi dan kondisi masyarakat Desa Seruni Mumbul, kami melakukan kegiatan tahap ke-ii dengan beberapa rangkaian kegiatan diantaranya: (a) melakukan pelatihan pembuatan handsanityzer sesuai standar WHO dan (b) memberikan pemaparan informasi terkait COVID-19. Tahapan terakhir dari kegiatan ini adalah evaluasi yang meliputi peningkatan wawasan dan keterampilan masyarakat. 


\section{HASIL DAN PEMBAHASAN}

Kegiatan pendampingan dan pembinaan ini diawali dengan mengobservasi kondisi masyarkat Desa Seruni Mumbul selama masa pandemi berlangsung. Adapun data awal yang digunakan sebagai representasi dari masyarkat adalah sejumlah warga yang telah berpatisipasi mengisi quisioner singkat online yang disebar melaui aplikasi WhatApps. Data yang dihimpun dari 247 respon yang masuk telah diplot seperti pada Gambar 1. Yaitu meliputi data usia, tingkat pendidikan, cara memperoleh informasi dan tingkat kepercayaan terkait informasi COVID-19.

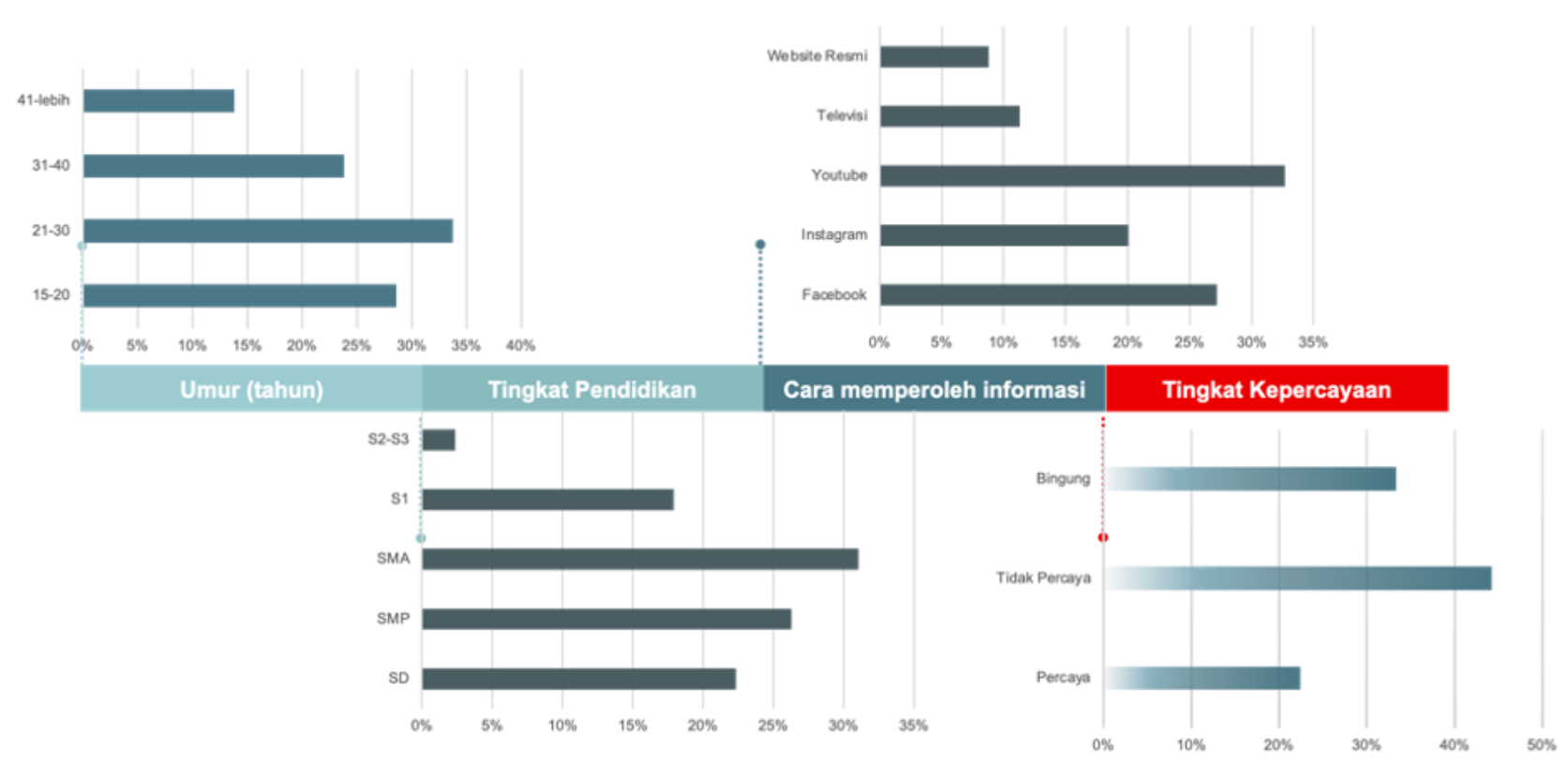

Gambar 1. Repersentasi kondisi masyarakat seruni mumbul berdasarkan usia, tingkat pendidikan, cara memperoleh informasi dan tingkat kepercayaan terkait informasi COVID-19.

Berdasarkan data yang diperoleh terlihat bahwa yang merespon quisioner terdiri dari berbagai usia, namun kami hanya mengambil batas usia minimal 15 tahun. Masyarakat yang memberikan tanggapan cukup merata dari berbagai kalangan usia, dimana didominasi oleh rentang usia 21-30 tahun (34\%) dan 15-20 tahun (28\%). Artinya lebih dari 50\% sampel masyarakat adalah kaum yang masih relatif muda. Hal ini penting untuk ditegaskan, mengingat tingkat emosional sangat ditentukan oleh usia (Mulati, 2017). Dominasi ini juga sesuai dengan perkiraan, dimana quisioner yang dilakukan secara online tentu membutuhkan penguasaan gawai yang cukup mumpuni, dimana hal ini sangat mudah kita temui dikalangan milenial. Meski demikian ternyata berdasarkan tingkat pendidikan respon, didominasi oleh lulusan SMA-sederajat mencapai 32\%, SMP-sederajat 26\% dan SD-sederajat mencapai $24 \%$. Artinya tingkat mendidikan tidak menghalangi masyarakat untuk bisa mengoperasikan gawai.

Dari parameter usia dan tingkat pendidikan juga berkorelasi dengan cara memperoleh informasi dimana, respon mayoritas memperoleh informasi terkait COVID-19 melalui media sosial yaitu channel youtube (33\%), Facebook (28\%) dan Instagram (20\%). Sedangkan yang memperoleh informasi dari televisi dan website resmi tidak lebih dari $15 \%$. Sehingga bisa dipastikan bahwa informasi yang sampai kemasyarakat adalah infromasi yang tidak valid, dimana media sosial bukanlah tempat untuk mencari informasi yang valid, melainkan setiap orang bebas untuk berpendapat dan 
menuliskan gagasan ataupun saling mengomentari. Hasil akhir dari data ini juga sesuai dengan dugaan bahwa, respons kebanyakan menyatakan bingung dan tidak peracya dengan adanya virus COVID-19.

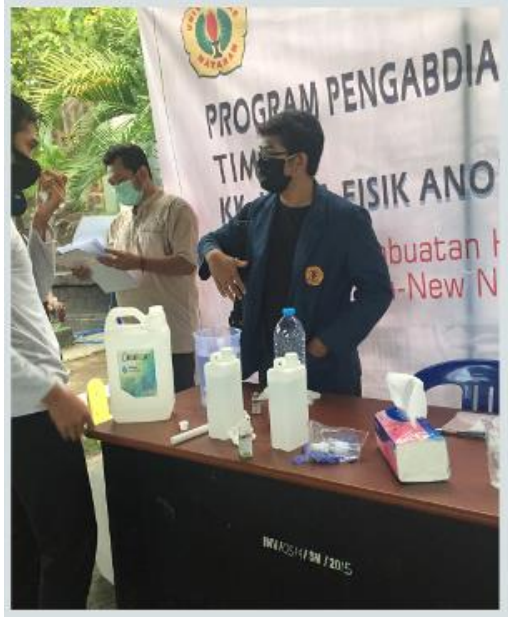

Relatihan Pembuatan Handsanityzer

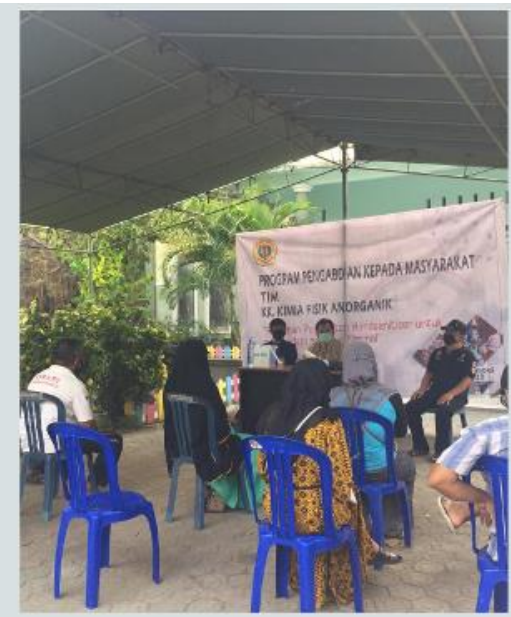

Sosialisasi Informasi Terkait COVID-19

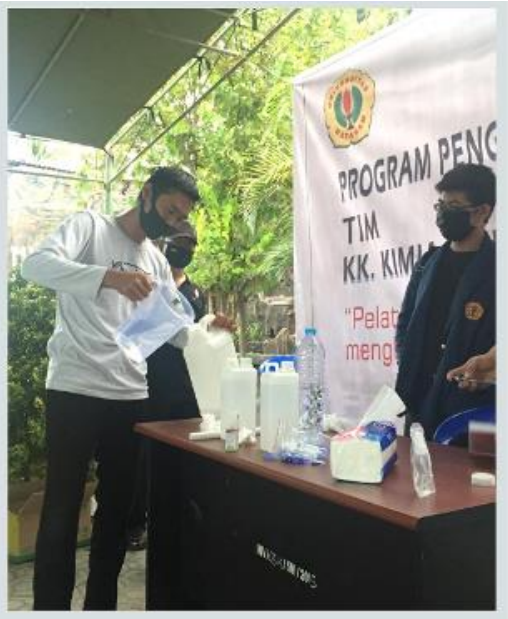

Bahan Sterilisasi

Yang Aman

Gambar 2. Dokumentasi Kegiatan pelatihan membuatan handsanitizer, bahan sterilisasi dan sosialisasi informasi terkait perkembangan COVID-19.

Oleh karena itu, digagaskan kegiatan pembinaan dan pendampingan terhadap aparat desa serta SATGAS COVID-19 ditingkat desa untuk menindak lanjuti hal tersebut. Adapun dari rangkaian kegiatan yang dilakukan yaitu (i) sosiaslisasi terkait informasi terupdate perkembangkang COVID-19 dengan pemaparan data dan bukti-bukti klinis, untuk menambah wawasan dan pengetahuan aparat desa selaku gerda terdepan ditingkat desa untuk bisa menyebarluaskan infromasi tersebut dengan sederhana.

Hal ini diharapkan dapat meningkatkan awerness masyarakat selama pandemi. Tidak hanya itu, kami juga memberikan workshop cara pembuatan Handisanitizer yang sederhana namun sesuai dengan standar anjuran WHO kepada aparat desa, mengingat Handsanitizer merupakan bahan penting selama massa pandemi ini untuk membentengi diri ditingkat dini, namun lanka dipasaran dan dengan harga yang relatif jauh lebih mahal dari biasanya. Meski beberapa riset dengan bahan herbal telah banyak dilakukan (Jatmiko Susilo, 2020).

Tabel 1. Formulasi Handsanitizer sesuai dengan yang distandarkan WHO

\begin{tabular}{llcc}
\hline \multirow{2}{*}{ Formula I } & \multicolumn{1}{c}{ Bahan Baku } & $\begin{array}{c}\text { Konsentrasi } \\
\text { Akhir(\%) }\end{array}$ & Volume (mL) \\
\cline { 2 - 4 } & Ethanol 96\% & 80,00 & 833,3 \\
\cline { 2 - 4 } & $\mathrm{H}_{2} \mathrm{O}_{2} 3 \%$ & 1,45 & 41,7 \\
\cline { 2 - 4 } & Gliserol 98\% & 0,125 & 14,5 \\
\hline \multirow{3}{*}{ Formula II } & \multicolumn{2}{c}{ Volume Total Akhir } & 1000 \\
\cline { 2 - 4 } & Isoprofil alkohol 99,8\% & 75,00 & 751,5 \\
\cline { 2 - 4 } & $\mathrm{H} 2 \mathrm{O} 23 \%$ & 1,45 & 14,7 \\
\cline { 2 - 4 } & Gliserol 98\% & 0,125 & 1000 \\
\hline
\end{tabular}


Formulasi handsaniter yang diterapkan pada kegiatan ini dibuat dalam dua formulasi. Bahan utama yang digunakan terdiri dari alkohol sebagai antiseptik (Singh, dkk., 2020), dimana pada formula I berupa ethanol sedangkan pada formula II berupa isoprofil alkohol yang lebih mild untuk kulit. Namun harga enthanol lebih terjangkau ketimbang isoprofil alkhol. Sedangkan komponen yang kedua berupa hydrogen proxide $\left(\mathrm{H}_{2} \mathrm{O}_{2}\right)$ yang merupakan jenis oksidator lemah. Penggunaan oksidator disini diharapkan sebagai perlindungan kedua setelah antiseptik, karena tidak jasad renik dapat dihalau oleh antiseptik. Penambahan gliserol pada formulasi ini sebagai pelembab kulit sebagi konsekuensi penggunaan alkhol yang dapat menyebabkan kulit kering (WHO, 2020).

Selain bahan-bahan pada Tabel 1., terdapat bahan tambahan berupa esensial oil atau minyak aroma terapi untuk menekan bau tidak sedap dari peroxide. Selain memberikan pelatihan untuk pembuatan hansanitizer, pada kegiatan ini juga tetap dipaparkan peran masing-masing komponen dalam formulasi ini, sehingga masyarakat mengetahui mana bahan yang dapat disubtitusi atau digantikan. Setelah melakukan kegiatan sosialisasi, workshop dan pendampingan, kami melakukan evaluasi terkait dengan pola kebiasaan masyarakat dalam mencuci tangan, prilaku/respon terhadap informasi COVID-19, penggunaan bahan sterilisasi dan tingkat kekhawatiran semasa pandemi. Pola kebiasaan masyarakat teramati banyak yang selalu membawa handsanitizer selama beraktifitas diluar ruangan.

\begin{tabular}{|c|c|c|c|}
\hline \multicolumn{2}{|l|}{$\begin{array}{l}\text { Tidak berubah secara } \\
\text { signifikan }\end{array}$} & \multicolumn{2}{|l|}{$\begin{array}{l}\text { Sekedarnya saja, } \\
\text { karena mahal }\end{array}$} \\
\hline Pola Keblasaan Mencucl Tangan & Perilaku & Penggunaan Bahan Strellsasi & Tingkat Kekhawatiran \\
\hline & $\begin{array}{l}\text { Masyarakat Cendrung } \\
\text { masih Cuek }\end{array}$ & & $\begin{array}{l}\text { Lebih cendrung cuek, } \\
\text { namun tetap optimis }\end{array}$ \\
\hline
\end{tabular}

Gambar 3. Pola prilaku masyarakat setelah pendampingan

Hal ini berkat dukungan kepala desa yang memoproduksi secara masal handsaitizer dan dibagi-bagikan kepada masyarakat, sesuai dengan arahan menteri bahwasanya dana desa dapat digunakan untuk kegiatan pencegahan COVID-19 (Shopihara, 2020). Namun kebiasaan mencuci tangan ternyata tidak berubah secara signifikan meski sarana cuci tangan telah dibuat disetiap gang perumahan. Masyarakat tetap hanya mencuci tangan pada aktifitas seperti biasa layaknya sebelum pandemi yakni hanya sebatas pada sebelum dan sesudah makan atau memang ketika tangan sedang kotor. Sedangkan penggunaan bahan sterilisasi seperti desinfectan secera barbar dapat ditekan, namun masyakarat tetap menggunaan yang sesuai standar hanya sekedarnya saja dikarenakan harga yang relatif mahal.

Sementara prilaku dan tingkat kekhawatiran masyarkat selama pandemi cendrung masih tetap cuek dengan teramati masih banyak masyakarat yang beraktifitas dilaur ruangan namun tidak menggunakan masker. Hal ini disebabkan oleh beberapa faktor diantara mayoritas mata pencaharian masyarakat adalah melaut dan berkebun, dimana aktifitas ini tidak melibatkan pembentukan kerumuman atau tidak melibatkan orang banyak pada suatu tempat. Selain itu, faktor lingkungan yang masih sangat religius juga menjadi faktor utama (Nastia, 2020), dimana masyarakat yakin bahwa kematian akan datang sesuai dengan kehendak tuhan melalui sakit atau bahkan tanpa sakit sekalipun tanpa dapat dicegah. Sosok panutan yang dapat dipercaya dan mumpuni dibidangnya juga sangat 
dibutuhkan selama pandemi ini. Karena berdasarkan hasil pantauan, masyarakat pedesaan yang masih sangat awam, relatif mengikuti sosok panutan yang ada didesa tersebut.

\section{KESIMPULAN DAN SARAN}

Pendampingan masyarakat pada masa pandemi yang dilakukan dengan serangkaian kegiatan seperti sosialisasi fakta-fakta ilmiah terkait COVID-19 dan memberikan pelatihan pembuatan handsanitizer sesuai dengan standar dan ketentuan memberikan dampak yang cukup signifikan. Kegiatan ini memberikan dampak yang positif kepada masyarakat Desa Seruni Mumbul, dimana pada masa pandemi banyak informasi yang kurang tepat beredar di masyarakat dan menyebabkan keresahan dapat ditangkal. Selain itu, produk kesehatan seperti Handsanitizer yang juga mengalami kelangkaan pada masa pandemi ini, dapat diatasi karena masyarakat berhasil membuat produk handsanitizer secara mandiri melalui pemerintah Desa. Oleh karena itu, kegiatan-kegiatan serupa sangat baik untuk dilakukan pada masa pandemi ini, untuk menjaga kondusititas dan kesehatan ditengah masyarakat.

\section{UCAPAN TERIMA KASIH}

Pemerindah Desa Seruni Mumbul Kecamatan Pringgabaya selaku binaan. Fakultas MIPA dan Lembaga Penelitian dan Pengabdian Kepada Masyarakat Universitas Mataram.

\section{DAFTAR PUSTAKA}

CNN Indonesia. (2020, Juni 24). Media Australia Sebut Indonesia Hotspot Corona Selanjutnya. Retrieved Juni 2020, from CNN Indonesia: https://www.cnnindonesia.com/internasional/20200624014811-113-516702/mediaaustralia-sebut-indonesia-hotspot-corona-selanjutnya

CNN Indonesia. (2020, Mei 1). Bukan 2 Juta, Kadin Sebut Korban PHK Akibat Corona 15 Juta. Retrieved Juni 2020, from CNN Indonesia: https://www.cnnindonesia.com/ekonomi/20200501181726-92-499298/bukan-2- jutakadin-sebut-korban-phk-akibat-corona-15-juta

COVID-19 NTB. (2020, Juni 24). COVID-19 NTB. Retrieved Juni 2020, from COVID-19. NTB: https://corona.ntbprov.go.id

Susilo, J., Erwiyani, A.R., Hati, A.K. (2020). Pembekalan Hand Hygiene Dan Pelatihan Pembuatan Hand Sanitizer Lidah Buaya (Aloe vera L.) di SMA Negeri 1 Ungaran Kabupaten Semarang. Indonesian Journal of Community Empowerment, 2(1), 11-20.

Mulati, T. S. (2017). Hubungan Kecerdasan Emosional Dan Umur Mahasiswi Semester I Div Kebidanan Tahun 2017. Jurnal Kebidanan dan Pengobatan Tradisional, 2(1), 1-5.

Gugus Tugas Percepatan Penangan Covid-19 Naional. (2020, Juni 25). Gugus Tugas Percepatan Penangan Covid-19 Naional. Retrieved Juni 2020, from Gugus Tugas Percepatan Penangan Covid-19 Naional: https://covid19.go.id

Nastia. (2020). Kearifan Lokal “Bahata” Sebagai Upaya Mencegah Covid-19 di Desa Lipu. Journal of Goverment and Political Studies, 3(2), 1-12.

Singh, D., Joshi, K., Samuel, A., Patra, J., \& Mahindroo, N. (2020). Alcohol-based hand sanitisers as first line of defence against SARS-CoV-2: a review of biology, chemistry and formulations. Epidemiology and infection, 148, e229. https://doi.org/10.1017/S0950268820002319 
Saputra, M. G. (2020, Juni 5). Penerapan New Normal, Pemerintah Umumkan 9 Sektor Ekonomi yang Kembali Dibuka. Retrieved Juni 2020, from Merdeka.com: Penerapan New Normal, Pemerintah Umumkan 9 Sektor Ekonomi yang Kembali Dibuka

Shopihara, I. J. (2020, Maret 22). Mendes PDTT: Dana Desa Bisa Dipakai untuk Pencegahan Covid-19.

https://kilaskementerian.kompas.com/kemendes/read/2020/03/22/09500521/mend es-pdtt-dana-desa-bisa-dipakai-untuk-pencegahan-covid-19

WHO. (2020, May 20). www.who.int. Retrieved from Guide to local production: WHOrecommended handrub formulations. https://www.who.int/publications/i/item/WHOIER-PSP-2010.5 